\title{
The Politicization of Interparliamentary Relations in the EU: \\ Constructing and Contesting the 'Article 13 Conference' on \\ Economic Governance
}

\author{
Ian Cooper \\ Department of Politics and International Studies (POLIS) \\ University of Cambridge \\ Alison Richard Building, 7 West Road, \\ Cambridge, UK CB3 9DT \\ ric31@cam.ac.uk
}

\begin{abstract}
Article 13 of the Fiscal Treaty (2012) prompted the creation of an interparliamentary conference to discuss and oversee the EU's post-crisis regime of economic governance. However, the first meeting of the "Article 13 Conference," in October 2013, was beset by conflict. Surprisingly, the main cleavage was not a leftright debate over economic policy (e.g. pro- vs. anti-austerity) but a debate about the nature and purpose of the conference itself. This pitted the European Parliament, preferring a weak conference with a narrow mandate, against a number of national parliaments that preferred a strong conference with a broad mandate. This cleavage was apparent in a series of constitutional, institutional and procedural disagreements which arose over the course of the setting-up of the Article 13 Conference, many of which remained unresolved even after its second and third meetings, in January and September 2014. At the root of this struggle lay competing visions for the parliamentary oversight of the EU: should scrutiny be centralized in the EP, or should there be a new system of joint scrutiny involving the EP and national parliaments together?
\end{abstract}

Keywords: National parliaments of the EU; European Parliament; inter-parliamentary conferences; parliamentary oversight; euro crisis; economic governance of the EU; "Article 13" Conference; Treaty on Stability, Coordination and Governance of the EU. 


\section{Introduction: Centralized vs. Joint Parliamentary Oversight of EU Economic Governance}

One easily overlooked provision in the Treaty on Stability, Coordination and Governance in the Economic and Monetary Union (the Fiscal Treaty) was Article 13. This provision anticipated that representatives of the relevant committees of the European Parliament (EP) and the national parliaments would come together in a conference to "discuss budgetary policies and other issues covered by this Treaty." Many saw this as merely a token of parliamentary oversight in a document that otherwise placed severe strictures on the budgetary autonomy of national parliaments. Nevertheless, spurred on by the continuing economic crisis, the parliaments of the EU rapidly made arrangements to bring the conference into being. The first meeting of the "Article 13 Conference" (as it is commonly known) took place in the Lithuanian parliament (the Seimas) in October 2013, a mere 18 months after the Treaty was signed and nine months after it came into effect. Yet despite its rapid creation, and in contrast to the normally placid atmosphere of interparliamentary conferences, the Vilnius meeting was punctuated by a number of sharp exchanges. This exposed some fundamental differences - in particular between the EP and a number of national parliaments, led by the Seimas - over how the conference should be established, organized, and run. This cleavage was apparent both prior to the Vilnius meeting and after, largely persisting into the second meeting of the conference (Brussels, January 2014) and the third (Rome, September 2014). ${ }^{1}$ The principal aim of this paper is to explain how the Article 13 Conference came into being, as well as to show how its construction has been dogged - and shaped - by this ongoing fundamental disagreement over its nature and purpose.

The early history of the Article 13 Conference may be understood as an instance of the politicization of interparliamentary relations in the EU. However, the principal cleavage among the participants was not a left-right divide over economic policy (e.g. pro- vs. anti-austerity), which is perhaps surprising given that this was the ostensible subject matter of the conference, as well as probably the most salient policy question facing the EU at that time. Nor was it a cleavage between proponents and opponents of European integration. Rather, the principal cleavage was over the

\footnotetext{
${ }^{1}$ This paper is based mainly on primary documents, interviews with a number of key participants, and direct (in-person) observation of the first three meetings of the Article 13 Conference.
} 
internal question (of little concern to the general public) of whether to create a weak conference with a narrow scope (as preferred by the EP and its allies) or a strong conference with a broad scope (as preferred by a number of parliaments, including the Seimas). For these purposes, a "weak" conference is one that cannot make collective decisions, whereas a "strong" conference has at least the minimal power to do so (e.g. by adopting non-binding "conclusions"); moreover, a conference with a "narrow" scope is focused on the implementation of the terms of the Fiscal Treaty, i.e. budgetary rules and economic policy coordination, whereas one with a "broad" scope covers a wider array of issues, including e.g. financial regulation. As this paper will demonstrate, this cleavage was apparent in most of the constitutional, institutional, and procedural disagreements that arose during the setting-up of the Article 13 Conference.

What exactly is the cleavage produced by the politicization of the Article 13 Conference, how does it affect democratic representation in the EU, and does the increased involvement of national parliaments enhance EU legitimacy? As it happens, all these questions are intertwined, because the conflict between the EP and national parliaments is arguably not merely a power struggle but a contest between competing models of parliamentary oversight in the EU. The EP, with the support of a few national parliaments, advocates a model of centralized oversight, in which there is only one EU-level parliamentary body exercising scrutiny over the EU - the EP itself. On the other hand, what many national parliaments are advocating - though less coherently, as their views are heterogenous - is a model of joint oversight, in which the task of EU scrutiny is performed by national parliaments and the EP together, at least in limited circumstances and/or within particular policy fields. By implication, in the first model, the Article 13 Conference is and ought to remain a body of marginal importance that merely enables interparliamentary consultation, whereas in the second model it should play a direct and robust role in the parliamentary oversight of EU economic governance. The two models also entail different notions of democratic representation in the EU. In the model of centralized oversight, national parliaments respect the division of labour between themselves and the EP, and focus their political activity on the national level. In the model of joint oversight, national parliaments have a legitimate role in representing their citizens at the EU level, and thus may become, individually and collectively, EU-level actors as embodied in such concepts as a "multilevel parliamentary field" (Crum and 
Fossum 2009), a "Euro-national parliamentary system" (Lupo and Manzella, eds. 2014), or a "virtual third chamber" (Cooper 2012, 2013). Only in the second model does the increased involvement of national parliaments substantially enhance the democratic legitimacy of the EU.

The EP made its own position on the new conference abundantly clear in a report of November 2012, stating the opinion that while it welcomes increased interparliamentary cooperation, this should not take the form of "...a new mixed parliamentary body which would be both ineffective and illegitimate on a democratic and constitutional point of view"; rather it stressed that the EP itself has "full legitimacy... as parliamentary body at the Union level for a reinforced and democratic EMU governance."2 This encapsulates the EP's insistence that parliamentary scrutiny of EMU should be centralized in the EP itself, and its rejection of a system of joint scrutiny - shared between the EP and national parliaments - as both ineffective and illegitimate. However, one problem with this position is that many of the new mechanisms of EU economic governance, including the Fiscal Treaty, were not made by the traditional community method, and so the powers of the EP over them are limited (Fasone 2014). In this situation, the approach of the EP is not to make common cause with national parliaments in devising a system of joint oversight, but rather to advocate for treaty change that would "communitarize" the policy field, and so bring it within the realm of the EP's centralized oversight.

Those who make the case for joint scrutiny argue that parliaments at multiple levels have an incentive to cooperate, as by working together they overcome information asymmetries with executive authorities - at both levels - and thereby better hold them to account; this is especially true in the EU, where powers are shared between levels and lines of accountability are blurred, and it applies in particular to areas of EU activity where decision-making is largely intergovernmental, such as foreign and security policy (Crum and Fossum 2009; Wouters and Raube 2012; Wagner 2013). The same logic could also be said to apply in the field of postcrisis economic governance in the EU, which has been dominated by intergovernmental decision-making. Conversely, it has been argued that the EP has a limited incentive to cooperate with national parliaments, even - or indeed especially -

\footnotetext{
${ }^{2}$ European Parliament, Report with recommendations to the Commission on the report of the Presidents of the European Council, the European Commission, the European Central Bank and the Eurogroup “Towards a genuine Economic and Monetary Union” 24/10/2012 (2012/2151(INI)), p. 19.
} 
in policy areas where intergovernmentalism prevails; acting strategically, the EP can better increase its institutional power either by exploiting treaty loopholes in order to maximize its competences under the current rules, or by increasing the normative pressure for treaty change that would bring the policy area in question under the control of the EP:

Ironically, therefore, it is precisely in areas with a strong intergovernmental component, where both NPs and the EP experience the greatest difficulties in exerting oversight and hence where inter-parliamentary cooperation would be most apposite and mutually beneficial, that competition over authority is likely to become a recurrent theme impairing inter-parliamentary relations (HerranzSurrallés 2014: 7).

The above sentence was in fact written in reference to the acrimonious negotiations between national parliaments and the EP that eventually resulted in the creation of the Interparliamentary Conference on CFSP-CSDP in 2012, but it could equally apply to the establishment of the Article 13 Conference in 2013.

It should be pointed out that the politicization of interparliamentary relations is not an altogether new phenomenon: it revives the long-standing debate over whether the relationship between the national parliaments and the EP is ultimately one of cooperation or conflict (Neunreither 1994, 2005). In fact, the early experience of the Article 13 conference broadly parallels the history of the creation of the other two major interparliamentary conferences in the EU: significant conflict between the EP and the national parliaments also beset the establishment of COSAC in 1989 (Knudsen and Carl 2008), and the Interparliamentary Conference on CFSP-CSDP in 2012 (Herranz-Surrallés 2014). The Article 13 Conference is such a new phenomenon that it is has received little scholarly study, and most of what has appeared thus far was written before its first meeting, and so is largely prospective (Fasone 2014; Hefftler and Wessels 2013; Kreilinger 2013; Maurer 2013). The present study feeds into the growing academic literature on the role of national parliaments in the EU after the Treaty of Lisbon (see e.g. Cooper 2012; Crum and Fossum, eds. 2013; Hefftler et al. 2015; Kiiver 2012; Raunio 2009). In particular, it is relevant for the debate concerning the role of national parliaments in the wake of the financial crisis (see e.g. Benz 2013; Maatsch 2014).

This body of this paper is structured around twelve questions (A-L) of three kinds - constitutional, institutional, and procedural - which were dealt with in the 
course of the setting-up of the Article 13 Conference. Constitutional questions (Section II) about how the conference should be established (e.g. its treaty basis), were followed by institutional questions (Section III) about how it should be organized (e.g. the frequency and location of its meetings) and procedural questions (Section IV) about what it should do (i.e. its agenda); finally, there is a brief conclusion (Section V). This structure allows the story to be told in roughly chronological order, yet it should be emphasized that there is significant overlap between the three kinds of questions, and they are all inter-related. In general, most of them refer back to one basic and still contested question: what is the appropriate model of parliamentary scrutiny of EU economic governance? Is it a system of centralized scrutiny, exercised by the EP alone, or joint scrutiny, shared between the EP and the national parliaments?

\section{Constitutional Questions: How Should the Conference be Established?}

Article 13 of the Fiscal Treaty called for an interparliamentary conference, but it was not self-evident exactly how, when, or by whom this body should be brought into being. Towards the end of 2012 it became clear that the Fiscal Treaty would soon pass into law (as it did on schedule on 1 January 2013) and this spurred parliaments to respond to Article 13. Around this time, there were a number of ad hoc interparliamentary meetings held to discuss the pending Article 13 Conference. In November 2012 the Chair of the European Affairs Committee (EAC) of the Danish parliament invited several of her counterparts from other EU parliaments to an informal meeting in Copenhagen to discuss the Article 13 conference, among other issues; this group sent a letter to European Council President Van Rompuy, who was then preparing his report on "Genuine Economic and Monetary Union."

Subsequently, in March 2013 the Danish parliament hosted a much larger follow-up meeting of EAC chairs from national parliamentary chambers, sixteen of which (who I will call the "Copenhagen group") sent another letter - this time to the Speaker of the Cypriot parliament who would chair the upcoming EU Speakers Conference outlining their views on the Article 13 Conference. In parallel to this, in January 2013 the Luxembourg parliament hosted a meeting of the speakers of parliaments of the six founding members of the EU, plus that of the EP (the "Luxembourg group") which produced a "working paper" stating their views on the Article 13 Conference; this too was sent to the Cypriot speaker. Then in April 2013 the Speakers of parliament from 
four ex-communist member states (the "Visegrad group") issued a joint declaration which stated their views on the Article 13 Conference. In addition to these, there were a number letters sent to the Cypriot speaker from individual parliaments, expressing views on the conference. ${ }^{3}$ These interventions concerned both constitutional questions (this section) and institutional questions (section III, below).

\section{A. What is the treaty basis for the conference?}

Strictly speaking, an interparliamentary conference within the EU does not require a treaty basis. The two oldest such bodies were established without one: the EU Speakers Conference (created 1963) has never been referenced in the EU treaties, and COSAC (created 1989) met regularly for many years before gaining recognition in the Treaty of Amsterdam (1997). As the parliaments of the EU are autonomous institutions enjoying their own democratic legitimacy and freedom of action, they can and often do join together in interparliamentary forums regardless of whether there is a treaty basis for such cooperation. However, an interparliamentary conference within the EU may derive some enhanced authority from having a treaty "foothold."

This said, as mentioned above the treaty article which foresaw the creation of this particular conference was Article 13 of the Fiscal Treaty, which reads as follows:

As provided for in Title II of Protocol (No 1) on the role of national Parliaments in the European Union annexed to the European Union Treaties, the European Parliament and the national Parliaments of the Contracting Parties will together determine the organisation and promotion of a conference of representatives of the relevant committees of the European Parliament and representatives of the relevant committees of national Parliaments in order to discuss budgetary policies and other issues covered by this Treaty.

While this treaty provision evidently provided the impetus for the creation of the "Article 13 Conference," its wording indicates that it does not actually establish the conference but merely foresees its creation; rather, it is up to the parliaments themselves to determine its organization and promotion. ${ }^{4}$ Moreover, it also refers to a provision of the Treaty of Lisbon, Title II of Protocol 1. This consists of two articles

\footnotetext{
${ }^{3}$ All of the above-mentioned correspondence, as well as the Conclusions of the Nicosia EU Speakers conference, is available on the Ipex website:

$<$ http://www.ipex.eu/IPEXL-

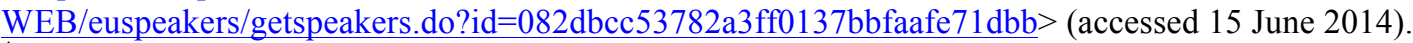

${ }^{4}$ See Kreilinger (2013: 8-10) on how the wording of Article 13 changed over the course of the negotiations of the Fiscal Treaty.
} 
under the heading, "Interparliamentary Cooperation," one concerned with interparliamentary cooperation generally and the other with the role of COSAC:

The European Parliament and national Parliaments shall together determine the organisation and promotion of effective and regular interparliamentary cooperation within the Union (Art. 9).

A conference of Parliamentary Committees for Union Affairs may submit any contribution it deems appropriate for the attention of the European Parliament, the Council and the Commission. That conference shall in addition promote the exchange of information and best practice between national Parliaments and the European Parliament, including their special committees. It may also organise interparliamentary conferences on specific topics, in particular to debate matters of common foreign and security policy, including common security and defence policy. Contributions from the conference shall not bind national Parliaments and shall not prejudge their positions (Art. 10).

The fact that Article 13 references this provision seems to indicate that the treaty basis for the conference, if it needs one at all, does not rest on Article 13 alone. The choice between the two treaty bases does have important implications, however. If the conference were founded solely on Article 13, then this would anchor it in the Fiscal Treaty, which would raise further questions about which interparliamentary institution should establish the conference, which member states' parliaments should be permitted to attend it, and what should be its overall scope (see Questions B, C and H, below).

Prior to the Vilnius conference, the EP and the Seimas argued over the correct treaty basis for the conference. The EP wanted it to be based primarily on Article 13, implying that the focus of the conference should be on "budgetary policies and other issues" covered by the Fiscal Treaty. With reference to Protocol 1 the EP wanted it based on Article 9 specifically, which says that the EP and national parliaments together determine the arrangements for interparliamentary cooperation. The Seimas responded by pointing out that Article 13 refers to Title II, which contains Articles 9 and 10, the latter of which gives a role to COSAC in the organization of interparliamentary conferences on specific subjects (see Question B below).

\section{B. Which interparliamentary institution should set up the conference?}

A more practical constitutional question regarding the new interparliamentary conference was, how was it to be created? Specifically, what should be the constitutive body that lays the groundwork for the establishment of the new 
conference, COSAC or the EU Speakers Conference? As it happens, this question was intertwined with the question of the treaty basis (see Question A above). Many national parliaments favoured establishing it through COSAC, a body which may take certain decisions by qualified majority vote. However, the EP favoured using the EU Speakers Conference, a smaller and lower-profile body which makes decisions by consensus. As the EU Speakers Conference brings together the persons who occupy what is generally the highest formal office in each parliament - the speaker/president - it can with some justice play a quasi-constitutional role in setting up new forms of interparliamentary cooperation. It did so, for example, in setting up and continuing to oversee IPEX, the electronic system for the exchange of information among EU parliaments. More to the point, a strong precedent was set the previous year when the EU Speakers Conference had established the Interparliamentary Conference on CFSP-CSDP at its meeting in Warsaw in April 2012. In that case, over the objections of some national parliaments - who had pointed out, rightly, that Article 10 of Protocol 1 seemed to give COSAC a clear mandate to organize an interparliamentary conference on this specific topic - the EP had prevailed. Given this precedent, it was commonly accepted from an early stage that the EU Speakers Conference would establish the new conference, as was done in Nicosia in April 2013. Even after the fact, the EU Speakers Conference in 2015 is still expected to conduct a review of the "arrangements" for the Article 13 conference, and may even be called upon to approve its Rules of Procedure (see Question K below).

\section{Which national parliaments should attend the conference?}

Given that the impetus for the conference came from the Fiscal Treaty, it was not clear whether parliaments from all member states of the EU should be represented there. Recall that the Fiscal Treaty is not formally part of the EU treaty framework but an agreement made under international law by $25 \mathrm{EU}$ member states, notwithstanding the fact that it is intended to be interpreted in harmony with, and ultimately incorporated into, the EU treaties (see Art. 16). This could be seen as providing grounds for excluding the parliaments of certain member states by virtue of either their disposition towards the single currency (e.g. non-Eurozone states, or states with a legal opt-out) or towards the Fiscal Treaty itself (e.g. non-signatory states, or 
states that have signed but not ratified). ${ }^{5}$ It was also unclear whether the parliaments of EU candidate countries or associated countries (e.g. EEA members) should be invited to attend as observers, as is the case at COSAC meetings.

Representatives of many national parliaments expressed their opposition to the prospect of their exclusion from, or unequal representation in, the Article 13 Conference. For example, the Marshal of the Polish Senate argued that non-Eurozone states should participate on equal terms by virtue of their obligation to eventually join the Euro: "The smooth running of the process of adopting the single currency requires the acceding country to be protected by the right to vote and participate in decisions concerning its future." In a similar vein the EAC of the Czech Senate stated its opinion that "representatives of national parliaments of those member states of the European Union that have not yet become parties to the [Fiscal Treaty] shall be allowed to participate in the conference from the beginning, at least as observers." Letters from the Visegrad group and the Copenhagen group stated the opinion that all EU member states should be represented at the conference.

In the end, the question was resolved with little conflict. The Nicosia Speakers conference stated that, "the Conference should consist of representatives from all the National Parliaments of Member countries of the European Union and the European Parliament...”. In the end, the first conference in Vilnius followed inclusive, broad-based rules of attendance: along with the EP, all the national parliaments of the EU were welcome to attend, and parliaments from the five candidate countries were invited to send observers. The second and third conferences followed similarly inclusive rules of attendance, with the exception that, for reasons that are unclear, the candidate countries were not invited to the Brussels conference in January $2014 .^{6}$

\section{Institutional Questions: How Should the Conference be Organized?}

The above constitutional questions had mostly been resolved by the time the EU Speakers Conference met in April 2013 to decide on more practical, organizational questions.

\footnotetext{
${ }^{5}$ At the time of the first Article 13 Conference, in October 2013, three EU member states were nonsignatories (Croatia, Czech Republic, the UK) and three signatory states had not completed the ratification process (Belgium, Bulgaria, the Netherlands).

${ }^{6}$ Representatives from the parliament of Norway, an EEA member but not a candidate country, attended the Brussels and Rome conferences as observers.
} 
D. Where and when should the meetings take place?

Questions of timing and location were resolved by the Speakers, who proposed that "...the Conference shall meet twice a year and be coordinated with the European Semester cycle." The two other major interparliamentary conferences, COSAC and the CFSP-CSDP conference, take place twice per year - normally between April-June and September-November - in the parliament of the member state holding the Council presidency. Some in the Copenhagen group suggested that the Article 13 Conference should take place on the margins of COSAC meetings, in order to save time and resources. Alternatively, the Luxembourg group suggested that while the meeting in the second half of the year should be hosted and chaired by the presidency parliament - as is the case with the other two major conferences - the meeting in the first half of the year should take place in the EP, and be co-hosted and co-chaired by the EP and the presidency parliament. The EP had just hosted a "European Parliamentary Week" in January 2013, in which almost all national parliaments participated, and it wanted to make this an annual event, perhaps in the context of the Article 13 Conference (see Question F below). It was the latter formula that found acceptance at the EU Speakers Conference. As a result, while the first meeting in Vilnius in October 2013 was hosted and chaired by the Seimas, the second meeting took place in Brussels in January 2014 and was co-hosted and co-chaired by the EP and the Greek parliament - as Greece held the Council presidency at the time.

But what was the rationale for holding the first Brussels meeting in January? After all, this is extremely early in the "European semester," as it takes place just after the Commission's publication of the Annual Growth Survey (AGS) at the end of the previous year, but prior to most of the key decision-making points in the cycle, such as when EU leaders endorse economic priorities based on the AGS (March), or when the Commission adopts country-specific recommendations (May-June) which are then debated and endorsed by national ministers and EU leaders (June-July). The apparent rationale for holding the meeting so early, according to an EP document explaining the European semester, is that in this way the EP may consult with national parliaments before holding its own debate on the AGS:

In February, the European Parliament (EP) expresses its opinion on the draft AGS in specific resolutions, also taking into account the contributions of the European Parliamentary Week meeting on the European Semester with National Parliaments 
held at the beginning of the year. ${ }^{7}$

What this implies is that the Article 13 Conference should not, as a body, formulate opinions or recommendations regarding the ongoing decision-making process in the European semester, and directly impart them to the EU institutions; rather, it should merely operate as a mechanism through which the EP may consult with national parliaments before making its own recommendations to the EU institutions. Thus the timing of the January conference lends credence to the EP's position as the preeminent parliamentary body on matters of EU economic governance, and the sole parliamentary interlocutor with EU-level institutions.

\section{E. What should the size of the delegations be?}

Delegation size has at times been a thorny question for EU interparliamentary conferences: specifically, should the EP delegation be the same size as, or larger than, national parliamentary delegations? This question had recently delayed the establishment of the CFSP-CSDP conference, before the EP obtained a compromise on a " $6+16$ " formula which allowed each national parliament to send six MPs, but the EP to send sixteen MEPs. Given this fraught history, it might have been expected that delegation size would prove a highly contentious issue regarding the Article 13 Conference, but ultimately it did not. The Luxembourg group endorsed use of the $6+16$ formula; by contrast the Copenhagen group expressed the opinion that the "European Parliament should be represented at the conference on equal footing with national parliaments." Ultimately, the issue was defused by the EU Speakers, who did not specify precise numbers: instead, they decided in their conclusions that "...the composition and size of each delegation rests upon each Parliament."

\section{$F$. Which meetings will the conference replace?}

Article 13 foresaw a "conference of representatives of the relevant committees" of the EP and national parliaments - but which are the relevant committees? The answer depends, ultimately, on the scope and purpose of the conference. If the focus of the conference is solely on monitoring national budgets, then the relevant committee is that concerned with budget and/or fiscal matters. Yet

\footnotetext{
${ }^{7}$ European Parliament, "The European Semester: Main steps at the EU level," 12.12.2013, p.1. Available at $<$ http://www.europarl.europa.eu/webnp/cms/pid/1975>, last accessed 15.06.2014.
} 
if the discussion also involves broader issues of financial regulation - e.g. banking then this implies that it should involve committees involved in broader financial and/or economic questions. Going further, it would be reasonable also to involve the committees on social affairs/employment or European affairs, the latter addressing questions with an EU dimension that cut across the above sectoral issues.

Complicating the picture still further, every parliament/chamber has its own committee system, where the tasks relevant to budgetary, economic, and financial issues may be distributed in an idiosyncratic way.

In the end, just as with delegation size, the EU Speakers worked around this problem by leaving it up to each parliament to decide which committees should be involved in the conference, stating simply that, "the composition and size of each delegation rests upon each Parliament." Even so, the EU Speakers' decision that the first Article 13 Conference should take place in late 2013 required the Lithuanian Seimas to rearrange its schedule of interparliamentary meetings and decide which ones to cancel in order to make way for the it. It cancelled two previously-scheduled meetings of committee chairs - one of economics committee chairs, and one combined meeting of economics and budget and finance committee chairs.

As for the second Article 13 Conference, held in the EP, it remained unclear whether it would be a separate event or combined with the "European Parliamentary Week" (EPW). The first EPW had taken place in January 2013: with some fanfare, the EP had hosted a large interparliamentary meeting to discuss economic policy coordination in the context of the European Semester. ${ }^{8}$ In the end the two events were combined, but it was left ambiguous whether the Article 13 conference replaced, merged with, or was subsumed by the EPW. The formal programme of the 2014 meeting leaves the impression that the Article 13 Conference is merely one event that took place within the EPW, rather than being identical with the EPW. ${ }^{9}$ The conference began with an "opening plenary session," which was addressed by the three presidents of the EP, the Commission and the European Council. Yet only after

\footnotetext{
${ }^{8}$ Some at the EP seem to have hoped that the EPW would itself suffice as the interparliamentary meeting foreseen in the Fiscal Treaty; when introducing the first meeting, Othmar Karas, VicePresident of the EP, expressed the hope that the EPW could be their "joint answer" to Article 13. ${ }^{9}$ From the EP website summarizing the event: "European Parliamentary Week (EPW) 2014 will take place from 20 to 22 January 2014 at the EP premises in Brussels. [...] Within its framework it will host the Interparliamentary Conference on Economic Governance (emphasis added). Available at $<$ http://www.europarl.europa.eu/webnp/cms/pid/1975>, last accessed 15.06.2014.
} 
this session was over (and Messrs. Schulz, Barroso and Van Rompuy had departed) did the actual "Interparliamentary Conference on Economic Governance of the EU (Art. 13 TSCG)" formally begin. Moreover, the programme also implied that the Article 13 Conference came to an end before the EPW formally concluded, so the final events, three parallel Interparliamentary Committee Meetings (ICMs) and a final wrap-up session, also technically took place outside the framework of the Article 13 Conference per se. The overall effect was to subtly downgrade the importance of the Article 13 Conference as an event, insofar as it seemed to be just one event among many that occurred during the EPW.

Going forward, it is as yet unclear what the future relationship will be between the EPW and the first-semester meetings of the Article 13 Conference.

\section{G. What should the name of the conference be?}

Disagreement over the nature and purpose of the conference even spilled over into a disagreement over what it should be called. Obviously its unofficial title, the Article 13 Conference, would not do, as it is meaningless to the general public. The full name of the Fiscal Treaty - the Treaty on Stability, Coordination and Governance in the Economic and Monetary Union - is itself too unwieldy to provide a basis for a name, and the EU Speakers conference conclusions did not recommend one. The Seimas decided to call it the Interparliamentary Conference on Economic and Financial Governance of the EU. This briefly caused friction with the representatives of the EP, who wished to replace the word "Financial" with "Fiscal." The rationale for the proposed change was to keep the focus on the issues raised by the Fiscal Treaty, i.e. budgetary matters; the EP was also concerned with protecting its own powers over the regulation of financial markets. Representatives of the Seimas insisted on retaining the word "financial," noting that in some parliaments, including their own, the committee dealing with fiscal matters is called the "Budget and Finance" committee, as distinct from the committee on "Economics."

The debate is not over, however, as the title for the second meeting, held in the EP in January 2014, dispensed with both "fiscal" and "financial" and was simply called the "Interparliamentary Conference on Economic Governance of the European Union." More recently, the Italian Parliament had intended to revert back to the title used in Vilnius, but the EP objected. As a result, the Rome meeting was held under the rather obscure title, "Conference under Article 13 of the Fiscal Compact." 


\section{Procedural Questions: What Should the Conference Do?}

Even after the main organizational questions were decided, it was still an open question what the substantive content of the conference would be - what issues would be discussed, which speakers would be invited, what decisions would be made. In short, what would be the agenda of the conference? The task of drafting an agenda fell to the parliament that was host and chair of the first meeting, the Seimas, which sought the approval of the other members of the Quartet - a group made up of the presidency troika (made up of the previous, current, and next presidency parliaments) and the EP. Among these four, the Seimas was generally supported by the Irish parliament (previous), and the EP was generally supported by the Greek parliament (next); and so the general disagreement discussed above was played out intensely in the negotiations between the members of the Quartet. And these disagreements continued right up to its last, particularly contentious, in camera meeting on the first day of the conference. Most of these remained unresolved even after the first meeting of the conference was over.

\section{H. What should be the scope of the conference?}

Article 13 envisioned a conference that would "discuss budgetary policies and other issues covered by this Treaty." However, in terms of substantive policy issues, the Fiscal Treaty is narrowly focused on reinforcing the system of budgetary rules and surveillance (Title III, the "Fiscal Compact"), economic policy coordination (Title IV), and governance of the euro area (Title V). On the face of it, this mandate is too narrow to provide for a wide-ranging debate on the multi-dimensional economic crisis facing the EU. In a move that discomfited the EP, the Seimas decided to expand the scope of the conference beyond the strict confines of the Fiscal Treaty; for example, one of the sessions on the agenda was a discussion of banking union - an issue that is without a doubt crucial with respect to the future economic and financial governance of the EU, but one that is not mentioned in the Fiscal Treaty at all.

A related question is, what should be the "ideological" scope of the conference? Implicit in the Fiscal Treaty and related reform measures is a particular macroeconomic analysis, that fiscal profligacy caused the economic crisis and only fiscal rectitude can resolve it; for this reason every Eurozone member must incorporate a balanced budget rule into national law, preferably as a constitutional 
rule that is beyond the reach of quotidian politics. In a conference based on Article 13 of the Fiscal Treaty, is it even possible to challenge the balanced budget orthodoxy embedded in that document with, for example, a proposal for a macroeconomic programme of budgetary expansion based on a Keynesian analysis? This remained an unresolved question at the first three meetings of the Article 13 Conference.

\section{What is the oversight function of the conference?}

If the purpose of the conference is to exercise a democratic oversight function, then whom exactly is it supposed to oversee? Were national parliaments to watch one another, or to "watch the watchers"? The Fiscal Treaty is one among many numerous measures - also including the "Six-pack" and the "Two-pack" - creating a system in which EU institutions are now "watchers" in that they conduct extensive and continuous surveillance of national budget processes. The fact that the conference is an outgrowth of the Fiscal Treaty could be seen to imply that national parliaments themselves are being enlisted to function as one more layer of surveillance, keeping an eye on one other to be sure their neighbours are not breaking the fiscal rules. A more benign version of this idea would be that national parliaments would use the conference as an opportunity to share "best practices" regarding obedience to the rules.

An alternative notion of an oversight function for the conference is that instead of watching each other, as above, they should "watch the watchers": that is, the EU's system of economic surveillance should itself be subject to robust parliamentary oversight. This again raises the question, should the oversight be centralized in the EP or exercised jointly with national parliaments? Certainly, there is a normative logic in involving national parliaments, as they are the institutions whose traditional budgetary powers are traduced by this new system of surveillance. As it is, parliamentary oversight of this system - whether exercised by the EP, national parliaments, or both - is rather weak. Besides Article 13, the only element of parliamentary oversight in the Fiscal Treaty is Article 12(5) which states that the President of the EP "may be invited to be heard" at the Euro Summit, and that the President of the Euro Summit "shall present a report" to the EP after each Euro Summit meeting.

The question of the conference's oversight function remained unresolved throughout the first three meetings. Whereas criticism of the EU's system of 
economic governance was relatively muted at the first conference in Vilnius, there was more vocal criticism in Brussels. During a session on "the democratic legitimacy of economic adjustment programmes," two MEPs from the ECON committee presented their draft report on the role and operations of the Troika, raising pointed questions concerning both its democratic legitimacy and its economic stewardship in relation to bailout countries. However, while they decried the fact that national parliaments have inadequate oversight over economic adjustment programmes, their proposed solution - to phase out the Troika and integrate the European Stability Mechanism (ESM) fully into the Community legal and institutional framework would effectively empower the EP as the parliamentary body that oversees such programmes. ${ }^{10}$ Once again the EP was concerned to promote a system of centralized, rather than joint, oversight.

\section{J. Which speakers should come to the conference?}

With respect to inviting the most important potential speakers, the Seimas was disadvantaged in that it was forced to arrange the conference on relatively short notice. The top priority of the Seimas (in keeping with the idea of "watching the watchers") was to ensure the participation of Olli Rehn, then the Commissioner for Economic and Monetary Affairs and the Euro, the one single EU official most closely associated with and responsible for the EU policy in this field. Rehn did participate, though by video-conference rather than in person, which dulled the exchange. Still, his presence set a precedent that the responsible Commissioner should in principle participate in the conference, answering direct questions posed to him by national parliamentarians. At the second conference, in Brussels, Rehn appeared in person, and perhaps for that reason he was subject to sharper questions and the exchange was more pointed.

Most of the other top officials invited to Vilnius - e.g. Christine Lagarde, Mario Draghi - were unable to attend. As mentioned above, the Brussels meeting in January 2014 was addressed by the top officials of the EU - the presidents of the EP, the Commission and the European Council. In retrospect, one advantage of having every second conference in Brussels is that it greatly increases the likelihood that the

\footnotetext{
${ }^{10}$ See the subsequent "Report on the enquiry on the role and operations of the Troika (ECB, Commission and IMF) with regard to the euro area programme countries,"

(2013/2277(INI)), 28.02.2014.
} 
most important officials will attend. The Rome meeting, by contrast, was organized more like an academic seminar than a parliamentary debate: most keynote speakers were academics, and none of the top EU officials attended. This was in part because the 2014-2019 Commission had not yet taken office. As it happens, Olli Rehn was present, but in the capacity of a newly elected MEP rather than as an outgoing Commissioner.

\section{$K$. Should the conference adopt Rules of Procedure?}

The question that provoked the most conflict at the first conference in Vilnius was whether to debate and adopt Rules of Procedure. Despite the limited time available for preparation, the Seimas had nonetheless prepared a draft Rules of Procedure, a 5-page document that set the basic parameters for the conference; in this, they were following the example set by the CFSP-CSDP conference, which had debated and adopted rules of procedure at its very first meeting in September 2012. Most controversially, the draft Rules of Procedure included a provision (at point 3.7) allowing for decisions to be taken by a 3/4 qualified majority vote when it was not possible to reach consensus; this was similar to COSAC, but different from the CFSP-CSDP conference, which takes decisions solely by consensus. The Seimas had tentatively scheduled time during the Vilnius conference for the draft to be debated and, at the end, adopted. Some parliaments commended the efforts of the Seimas in preparing it, and a number of delegations (from Estonia, France, Poland and the UK) proposed amendments to the draft, on the presumption that this document would provide the basis for the debate in Vilnius.

The EP, however, was adamantly opposed even to debating, let alone adopting, Rules of Procedure; this position received crucial support from the German Bundestag, whose head of delegation sent a letter welcoming a general debate on its "aims and functions" but stating the opinion that it would be "premature" to adopt Rules of Procedure. In the face of this pressure, the debate on the draft Rules of Procedure was removed from the official conference agenda. However, this removal did not prevent it from being brought up spontaneously during the debate on the overall "purpose and vision" of the conference, in particular by national parliamentarians annoyed by what they saw as the EP's obstructionism. One Dutch MP, Anne-Wil Lucas, found it absurd that instead of debating the rules of procedure, 
as originally planned, the conference was having a procedural debate over whether to debate the rules of procedure - a situation she called "Kafkaesque."

In the end, no rules of procedure were adopted. Even so, an agreement was made in principle to begin a "Vilnius Process" wherein a working group would aim to agree upon Rules of Procedure in 2014, using the Seimas draft as a basis. However, three months later, at the Brussels meeting, discussion of the Rules of Procedure and the Vilnius Process were entirely absent from the agenda; neither was there a meeting of the Quartet, as there had been in Vilnius. During the opening session, a parliamentarian from the Lithuanian delegation decried the fact that these items were off the agenda. In response to the Lithuanian complaints, the co-chairs from the Greek parliament and the EP assured them that the Greek parliament would continue the Vilnius Process by making consultations with other national parliaments, with a view to finalizing Rules of Procedure under the Italian Presidency in the latter half of 2014. ${ }^{11}$

A debate over the Rules of Procedure was scheduled to take place at the third Article 13 Conference, in Rome. However, at the outset of the conference the Speaker of the Italian Camera dei Deputati announced that the Rules of Procedure would not be adopted there, but would instead be approved by the next EU Speakers Conference, in Rome in the spring of 2015. During the subsequent debate, many national MPs expressed dismay at this, suggesting instead that the conference adopt its own Rules of Procedure there and then, rather than leave the matter to the Speakers. Nevertheless, the meeting broke up without any final decision. Instead, the Italian parliament promised to consult further and to produce a final draft of the Rules of Procedure.

\section{Should the conference adopt conclusions?}

As part of its preparations for the conference, the Seimas had drafted a 4-page document entitled, "Conclusions," which set out, in general and largely uncontroversial terms, the main points discussed at the conference. Yet, as happened

\footnotetext{
${ }^{11}$ In February 2014, the chairs of the committees on European and Economic Affairs of the Greek parliament sent a letter to the other parliaments soliciting their suggestions for amendments to the Rules of Procedure, to which numerous parliaments responded. This correspondence may be found on the IPEX website:

$<$ http://www.ipex.eu/IPEXLWEB/euspeakers/getspeakers.do?type $=082 \mathrm{dbcc} 5420 \mathrm{~d} 8 \mathrm{f} 480142510 \mathrm{~d} 09574 \mathrm{e} 02$ \&appLng $=\mathrm{EN}>$ (accessed 15 June 2014).
} 
with the draft Rules of Procedure, the EP was adamantly opposed to the new conference adopting any conclusions at all, regardless of their substantive content. As any conference conclusions must (at least in the first instance) be approved by unanimity, the EP could effectively veto any conclusions proposed by the Seimas. Eventually the EP agreed to the adoption of a document, which led to a semantic searching for a more innocuous label to attach to the document formerly known as "Conclusions." Call it a "Press Release"? "Declaration"? "Communication"? "Communiqué"? Eventually, the Seimas proposed calling it a "Contribution," which the EP accepted. The Seimas was satisfied with this term because at another interparliamentary conference - COSAC - the "Contribution" actually carries more weight than the "Conclusions." At every meeting, COSAC adopts two documents, entitled "Conclusions" and "Contribution." The COSAC "Conclusions" is generally an internally-focused, housekeeping document, whereas the "Contribution" is an outward-focused, explicitly political document, addressed to the EU institutions and the world at large.

Yet the disagreement over concluding documents did not end there. At the EP's insistence, most of the substantive content of the original "Conclusions" had been stripped away to produce the "Contribution." However, the Seimas did not discard these substantive conclusions, but rather repackaged them as a document called "Presidency Conclusions" - that is, conclusions endorsed by the presiding parliament, though not necessarily by the whole conference. This was a canny formulation, because it is the term used for the concluding document of the EU Speakers Conference. Indeed, it was the "Presidency Conclusions" of the EU Speakers Conference in Nicosia that had set the groundwork for the Article 13 Conference in the first place. In this way the Seimas managed to obtain its goals of having some kind of concluding document that spoke for the conference as a whole (the "Contribution") and a document that summed up the main political points of the conference (the "Presidency Conclusions").

As for the second Article 13 Conference, in Brussels in January 2014, no Conclusions were debated or adopted there; like the Rules of Procedure, the item was left entirely off the agenda. At the Rome meeting, the Italian presidency did not put forth any broad "Conclusions" for the conference to adopt. It did produce a final document, however, outlining the main points discussed at the conference, which it modestly entitled, "Presidency Summary." 


\section{Conclusion}

The world of interparliamentary cooperation has recently undergone a major upheaval. Until recently there was just one permanent interparliamentary conference - COSAC - but with the creation of the CFSP-CSDP and Article 13 Conferences, there are now three. All three conferences have a treaty foothold, giving them a legalconstitutional status that separates them from the many merely ad hoc interparliamentary meetings. Yet the degree to which the early history of the Article 13 Conference was politicized shows that the emerging role of national parliaments in the EU is still deeply contested. From the point of view of the EP, these bodies are and should remain marginal, as the only fully effective and democratically legitimate system of parliamentary oversight of the EU is one that is centralized in the EP. On the other hand, it may be argued that while these bodies have little or no autonomous decision-making authority, and the actions of the delegates cannot bind their respective home parliaments, they exercise a form of joint scrutiny that is more robust than if each parliament were to do so on a purely individual basis. While the principal oversight function of each individual national parliament is still to scrutinize its own government in its conduct of EU affairs, in recent years national parliaments have also assumed an important collective role, which they exercise alongside the EP, in the oversight of the activities of the EU. The latter form of scrutiny is particularly appropriate in areas such as foreign policy and economic governance, in which EU action is largely non-legislative, where powers of the EP are limited, and where sensitive issues of national sovereignty are raised; hence the new interparliamentary conferences which have recently been created in these areas. However, it should be clear from the forgoing that, of these two competing models of parliamentary scrutiny in the EU, it is yet to be determined which will ultimately prevail.

\section{Acknowledgements}

I would like to thank the organizers of workshops where previous versions of this paper were presented, at the University of Oslo (John Erik Fossum and Andreas Føllesdal), at the Hanse-Wissenschaftskolleg in Delmenhorst (Richard Bellamy and Sandra Kröger), the University of Cambridge (Julie Smith) and at the LUISS Center for Parliamentary Studies in Rome (Nicola Lupo). For many helpful comments, I thank all the workshop participants, Dario Castiglione, the editors of this special 
issue, and two anonymous referees. I would also like to thank the Lithuanian Seimas, the European Parliament, and the Italian Camera dei Deputati for their hospitality in permitting me to attend the meetings as an observer.

\section{References}

Benz, Arthur. 2013. "An Asymmetric Two-Level Game: Parliaments in the Euro Crisis," in Ben Crum and John Erik Fossum, eds., Practices of InterParliamentary Coordination in International Politics: The European Union and Beyond, (European Consortium for Political Research Press), pp.125-140.

Cooper, Ian. 2013a. "Bicameral or Tricameral? National Parliaments and Representative Democracy in the European Union," Journal of European Integration 35 (5): 531-546.

Cooper, Ian. 2012. “A 'Virtual Third Chamber' for the European Union? National Parliaments After the Treaty of Lisbon. West European Politics 35(3): pp. 441-465.

Crum, Ben and John Erik Fossum, eds. 2013. Practices of Inter-Parliamentary Coordination in International Politics: The European Union and Beyond, (Colchester: European Consortium for Political Research Press).

Crum, Ben and John Erik Fossum, 2009. "The Multilevel Parliamentary Field: A Framework for Theorizing Representative Democracy in the EU," European Political Science Review 1(2): 249-271.

Fasone, Cristina. 2014. "European Economic Governance and Parliamentary Representation. What Place for the European Parliament?" European Law Journal 20 (2): 164-185.

Hefftler, Claudia, Christine Neuhold, Olivier Rozenberg, and Julie Smith (eds.) 2015: Palgrave Handbook on National Parliaments and the European Union. Basingstoke: Palgrave Macmillan.

Hefftler, Claudia and Wolfgang Wessels. 2013. "The Democratic Legitimacy of the EU's Economic Governance and National Parliaments," IAI Working Papers $13 / 13$.

Herranz-Surrallés, Anna 2014. "The EU's Multilevel Parliamentary (Battle) Field: Inter-parliamentary Cooperation and Conflict in Foreign and Security Policy" West European Politics, forthcoming.

Kiiver, Philipp. 2012. The Early-Warning System for the Principle of Subsidiarity: Constitutional Theory and Empirical Reality. Abingdon: Routledge.

Knudsen, M. and Y. Carl, 2008. "COSAC - Its Role to Date and its Potential in the Future," in G. Barrett (ed.), National Parliaments and the European Union: The Constitutional Challenge for the Oireachtas and Other Member State Legislatures. Dublin: Clarus Press, 455-483. 
Kreilinger, Valentin 2013. The New Inter-Parliamentary Conference for Economic and Financial Governance, Policy Paper 100 (Notre Europe - Jacques Delors Institute).

Manzella, Andrea and Nicola Lupo, eds. 2014. Il Sistema Parlamentare EuroNationale. Lezioni, Torino, Giappichelli.

Maatsch, Aleksandra. 2014. "Are we all austerians now? An analysis of national parliamentary parties' positioning on anti-crisis measures in the eurozone," Journal of European Public Policy 21(1): 96-115.

Maurer, Andreas. 2013. "From EMU to DEMU: The Democratic Legitimacy of the EU and the European Parliament, IAI Working Papers 13/11.

Neunreither, Karlheinz. 2005 "The European Parliament and National Parliaments: Conflict or cooperation?" Journal of Legislative Studies 11(3-4): 466-489

Neunreither, Karlheinz. 1994. “The Democratic Deficit of the European Union: Towards Closer Cooperation between the European Parliament and the National Parliaments" Government and Opposition 29:(3): 299-314.

Raunio, Tapio. 2009. National Parliaments and European Integration: What we know and what we should know. ARENA Working Paper. Oslo.

Wagner, Wolfgang (2013), "Who is Coming? Attendance Patterns in the NATO and WEU Parliamentary Assemblies," in Ben Crum and John Erik Fossum, eds., Practices of Inter-Parliamentary Coordination in International Politics: The European Union and Beyond, (European Consortium for Political Research Press), pp. 195-211.

Wouters, Jan \& Kolja Raube (2012) "Seeking CSDP Accountability Through Interparliamentary Scrutiny", The International Spectator: Italian Journal of International Affairs 47(4): 149-163. 